\title{
Hemophilia A
}

INSERM

\section{Source}

INSERM. (1999). Orphanet: an online rare disease and orphan drug data base. Hemophilia A. ORPHA:98878

Hemophilia A is the most common form of hemophilia (see this term) characterized by spontaneous or prolonged hemorrhages due to factor VIII deficiency. 